\title{
Ukrainian Migration Aspirations towards Germany: Analysis and Development Scenarios
}

\author{
Vitalii Boiko iD https://orcid.org/0000-0003-3968-1651 \\ Dr, Professor, Department of Management of Organizations, Lviv Polytechnic \\ National University, Lviv, Ukraine, e-mail: vitalii.v.boiko@lpnu.ua
}

Olha Mulska iD https://orcid.org/0000-0002-1666-3971

Ph.D., Senior Research Fellow, Department of Social and Humanitarian

Development of Regions, M. Dolishniy Institute of Regional Research, National

Academy of Sciences of Ukraine, Lviv, Ukraine, e-mail: oliochka.mulska@gmail.com

Ihor Baranyak (iD) https://orcid.org/0000-0002-1467-0262

Junior Research Fellow, Department of Social and Humanitarian Development

of Regions, M. Dolishniy Institute of Regional Research, National Academy

of Sciences of Ukraine, Lviv, Ukraine, e-mail: ihorbaranyak@gmail.com

\section{Olha Levytska (iD https://orcid.org/0000-0001-8174-9918}

Ph.D., Senior Research Fellow, Department of Social and Humanitarian

Development of Regions, M. Dolishniy Institute of Regional Research, National

Academy of Sciences of Ukraine, Lviv, Ukraine, e-mail: o.levytska@gmail.com

(Corresponding Author)

\begin{abstract}
Based on the multiple regression model and scenario approach to forecasting, the article estimates the Ukrainian migration aspirations towards Germany (the scale of migration, the economic activity of migrants, and their economic benefits). It is argued that major transformations in the gender-age structure of the German population may cause a demographic crisis and labour market imbalances. Our projections indicate the growing role of foreign human resources in the German economy. When modelling the scale of emigration from Ukraine, an integrated approach is applied, considering not only trends of pull-push factors but also special aspects of the German
\end{abstract}


migration policy and the outflow of 8-10 million Ukrainian migrant workers. Given the poor statistical data on the scale of labour emigration needed for constructing reliable econometric models, the use of expert forecasting method remains the most optimal technique for assessing potential migration flows and migration systems.

Keywords: migration aspirations, socio-economic factors, forecast, migration policy, Ukraine, Germany

JEL: F22, J11, O15

\section{Introduction}

Individual characteristics such as age, gender, education, religion, marital status and personal attitudes towards migration have a significant impact on making the final decision to migrate. These are the micro-level factors, which along with the macro drivers (social, economic, political and ecological factors) determine migration processes, especially the potential scale of international migration. In this context, forecasts of migration aspirations, the socio-economic conditions, and the prospects for their future change play an important role in developing effective migration policies.

Transformation processes in the Ukrainian economy, burdened by the global financial and economic crisis, have intensified migration flows and resulted in growing migration aspirations of the population towards the countries of the EU area (e.g., Poland, Germany, the Czech Republic, and Italy). International migration partially compensates for ageing and population decline, meets labour demand for low-paying jobs and jobs with poor working conditions, increases private emigrants' transfers to donor countries, and reduces the budgetary burden in the social sphere (savings of pension and social benefits). However, excessive migration aspirations exert additional pressure on state budgets, deform the age structure of the population, create labour shortages, reduce a country's intellectual potential, and decrease budget revenues because of a fall in the number of potential taxpayers.

In this regard, the development of a system of estimates and forecasts of population migration, aimed at solving the problems outlined above, is relevant due to the formation of new migration systems and networks. Such a system is crucially important for Ukraine, which is one of the largest migrant donor countries for the EU, USA, and Canada. In these recipient countries, the immigrant population is becoming more significant, given a decreasing impact of natural changes on population dynamics, which is a particular challenge for Germany, Italy and Poland, already experiencing zero or negative natural population growth ("Kurier" 2018). 


\section{Literature review}

International migration is a complicated phenomenon that is difficult to tackle and measure. Forecasting such processes is challenging, characterised by a high error rate, the highest among the three demographic parameters (fertility, mortality and migration). Therefore, many modern methods of forecasting future trends and characteristics of population migration require improvement to better address the emerging challenges in the socio-demographic sphere. Considering most of the existing influencing factors, Libanova $(2009 ; 2010)$ thoroughly studied social and economic characteristics of external labour migration in Ukraine, paying particular attention to the directions of labour emigration, the living and working conditions of the Ukrainian nationals abroad, labour migrants' earnings and remittances, and the impact of labour migration on the development of the labour market in Ukraine.

Experts from the Ptoukha Institute for Demography and Social Studies of the National Academy of Sciences of Ukraine (Poznyak and Shevchuk 2014; Sarioglo 2016), working on issues related to migration forecasting, discovered the influence of socio-economic factors on the formation of migration systems. Meanwhile, analytical assessments of labour and educational migration, the development of a conceptual framework for migration policy, as well as the inclusion of diaspora issues into the research methodology at the National Institute for Strategic Studies of Ukraine are presented in various scientific publications by Malynovska (2013; 2015a; 2015b).

With the escalation of the military conflict in the east of Ukraine, the problem of an increasing number of internally displaced persons arose, along with their social protection and the development of appropriate state policy. In addition, other important issues relating to internal migration flows, potential migrants to EU countries, their motivational attitudes, as well as the mechanisms for regulating internal and external migration have been fully considered by the experts from the Dolishniy Institute of Regional Research of the National Academy of Sciences of Ukraine (Bil 2017; Sadova et al. 2019).

Significant environment fluctuations in the national labour market, foreign policy uncertainty, and the continuously unstable economic situation in the country have not helped the development of the long-term forecasting concept. Therefore, the short-term forecasting of regional migration is most common among Ukrainian scientists (Ovchynnikova 2017).

Migration processes in Eastern Europe and Central Asia draw the attention of many researchers and policymakers since these processes have been conditioned by political (the collapse of the Soviet system in 1990, the emergence of conflicts and new states, the opening of European borders) and economic factors (the decline in the living standards, low wages, minimum social security, etc.). As outlined by Mansoor and Quillin (2006), in the countries of the former Soviet Union, multiple waves of migration started to get out of the authorities' control, forming new migration vectors and systems. Mahmoud, Trebesch and Trebesch (2010) analysed labour migration based on the microdata from unique household surveys conducted in Belarus, Bulgaria, Mol- 
dova, Romania and Ukraine. According to their research, the undercount of migration makes it impossible to predict a country's economic development and to create conditions for balancing a national labour market, but it does not contribute to effective migration policymaking.

In terms of globalisation, the role of migrant remittances and re-emigration as the main factors that affect the development of migration donor countries is particularly important. For instance, Wickramasekara (2008) studied globalisation and its implications for international labour migration and the protection of employee rights.

It should be stressed that there is no reliable data on international migration in many countries of the world. Thus, Hyndman and Booth (2008) estimated net migration as the difference between historical data on an annual population and successive populations one year ahead from the forecast using data on fertility and mortality. They obtained specific population projections by age and gender based on modelling (the Monte Carlo method) future fertility, mortality and net migration, which were combined in a cohort-component method.

Keilman and Pham (2004) paid significant attention to the forecast of three major demographic variables (fertility, mortality and migration), analysing the empirical errors that have been observed in the forecasting methodology of 14 European countries since 1950. Bijak (2006) also explored methodological issues and regarded socio-economic forecasts as those that can be based either on general patterns and theories or on special models developed with consideration of migration theories. His models are widely used for modern migration forecasts.

Based on the above arguments, we defined two hypotheses of the research:

Hypothesis 1: The formation of the Ukraine-Germany migration vector takes place under a long-lasting and mostly one-sided influence of socio-economic factors that transformed the migration behaviour of Ukrainian emigrants.

Hypothesis 2: The demographic situation and labour market conditions in Germany vary depending on migration flows from the countries that are the primary donors of the labour force (including Ukraine).

The main objective of the research is to analyse and model the Ukraine-Germany migration vector. Accordingly, the article consists of five sections, containing research methodology, the results of analysing and modelling the Ukraine-Germany population migration vector, conclusions and the authors' proposals.

\section{Methodology}

The algorithm for predicting Ukrainian migration to Germany is complicated by the demographic trends of the two countries, their economic growth trends, and changes in the labour market conditions.

To confirm the first hypothesis, a multiple linear equation of direct dependence (variation) (1) was composed, allowing us to calculate the partial effect of each factor 
on the dependent variable (the intensity of Ukrainians' immigration to Germany). The dependence of the immigration intensity coefficient, which is expressed as the number of Ukrainians who went to Germany per 1,000 local German population. The dependence of the coefficient on selected socio-economic factors is determined using the Least Squares method with instrumental variables (NLS), which considers the possibility of mutual causality between dependent variables.

$$
\begin{aligned}
C O E F_{t}= & \alpha_{0}+\alpha_{1} I N F_{t}^{U A}+\alpha_{2} E F_{t}^{E C}-\alpha_{3} S A L_{t}^{G E R M}- \\
& -\alpha_{4} S A L_{t}^{U A}-\alpha_{5} U N E M P_{t}^{G E R M}
\end{aligned}
$$

where $\mathrm{COEF}_{t}$ is the coefficient of the intensity of Ukrainians' migration to Germany (index, current year vs previous one); $I N F_{t}^{U A}$ is the inflation rate in Ukraine; $E F_{t}^{E C}$ is the economic benefits of Ukrainians which they achieve in the labour market in Germany (index, current year vs previous one); $S A L_{t}{ }^{G E R M}$ is the average wage in Germany, $S A L_{t}{ }^{U A}$ is the average wage in Ukraine (index, current year vs previous one); UNEMP $t_{t}^{G E R M}$ is Germany's unemployment rate.

Annual data provided by the Statistical Offices of Ukraine and Germany for 20062017 are used. The personal economic benefits of Ukrainian labour migrants in Germany are calculated as the difference between the wages (and other types of income) received by employed Ukrainian migrants in Germany, and those of the potential income earned by Ukrainians had they remained participants of the labour market in Ukraine.

The results of model (1) are presented in Table 1. All the factors' values and the dependent variable are reduced to homogeneous series (standardised data), which makes it possible to obtain high validity estimates of the model using the coefficients of determination, the adjusted coefficient of determination, and the coefficient of the Durbin-Watson statistic (Table 3).

Table 1. Validity coefficients for the model variables

\begin{tabular}{|l|c|c|c|c|}
\hline \multicolumn{1}{|c|}{ Variable } & Estimated coefficient & Standard error & t-statistic & p-value \\
\hline INF $^{\mathrm{UA}}$ & 0.3492 & 0.1870 & 1.8668 & 0.1112 \\
\hline EF $^{\mathrm{EC}}$ & 0.8248 & 0.5769 & 1.4297 & 0.2028 \\
\hline SAL & -0.2842 & 0.1990 & -1.4286 & 0.2030 \\
\hline SAL & -0.5750 & 0.7538 & -0.7628 & 0.4745 \\
\hline UNEMP & -0.6988 & 0.4060 & -1.7211 & 0.1360 \\
\hline
\end{tabular}

Source: authors' calculations.

To confirm the second hypothesis, the size of the Ukrainian community in Germany was predicted based on a scenario approach, namely on modelling the reference, optimistic, tendentious and pessimistic patterns. This approach implies considering the modelled socio-economic factors (1) that influence migrants' aspirations within the Ukraine-Germany migration vector. 


\section{Results and discussion}

\section{Analysis of the Ukraine-Germany migration vector}

According to the results of the International Organization for Migration research (Sadova et al. 2019), Germany is the second most popular emigration destination for Ukrainians (after Poland) in the list of the most attractive countries to work in. At the same time, the main pull-factor for migrants from Ukraine is the relatively high values of wage rates in recipient countries. Between 2006 and 2017, the average salary of Ukrainians living in Germany was five times higher than the Ukrainian national indicators.

Concerning the number of Ukrainian labour migrants, the situation is not clear. Domestic statistical institutions do not keep complete records of the data necessary to conduct a detailed analysis and draw comprehensive conclusions. The available information is also called into question since there are significant differences in the quantitative estimates of migration intensity and flows of migrants. According to the State Statistics Service of Ukraine, approximately 22,000 people emigrated from Ukraine to Germany between 2005 and 2017 (State Statistics Service of Ukraine n.d.), while according to the German statistical service, it was 115,000 people (Ausländische Bevölkerung n.d.). The undercount of migrants in the Ukrainian data amounts to 5-10,000 people every year. We should mention that the gap in statistical data of the two countries reached a maximum of 13,000 people in 2016 (Figure 1).

The analysis shows that the number of Ukrainians legally staying in Germany is growing, and in 2017, it was equal to 138,000 people. However, according to the State Migration Service of Ukraine, the number of Ukrainian nationals who were on the consular register in Germany between 2014 and 2017, varied between 105,000 and 113,000 people (State Migration Service of Ukraine 2017), which is $20-25 \%$ less than Germany's official statistics. Such a difference in estimates indicates the reluctance of Ukrainians to register their official residence, as well as their distrust of the representative bodies of Ukraine in Germany.

Between 2004 and 2013, based on official German statistics, the number of Ukrainians who arrived in Germany exceeded the number of departures. Between 2005 and 2017, 115,000 arrived, while almost 63,000 thousand emigrated. The number of Ukrainians has decreased mostly due to their acquisition of German citizenship rather than outflows of migrants. Thus, according to official data for the period 1998-2017, about 3,500 Ukrainian migrants per year changed their Ukrainian citizenship for German (Einbürgerungen (n.d.) - year 2017).

There are many cases when the departure of Ukrainian citizens for permanent residence is carried out without an official appeal to the authorities. Therefore, Ukrainian emigrants who have obtained foreign citizenship without undergoing the relevant procedures in Ukraine are still considered Ukrainian nationals (State Migration Service of Ukraine 2017). 


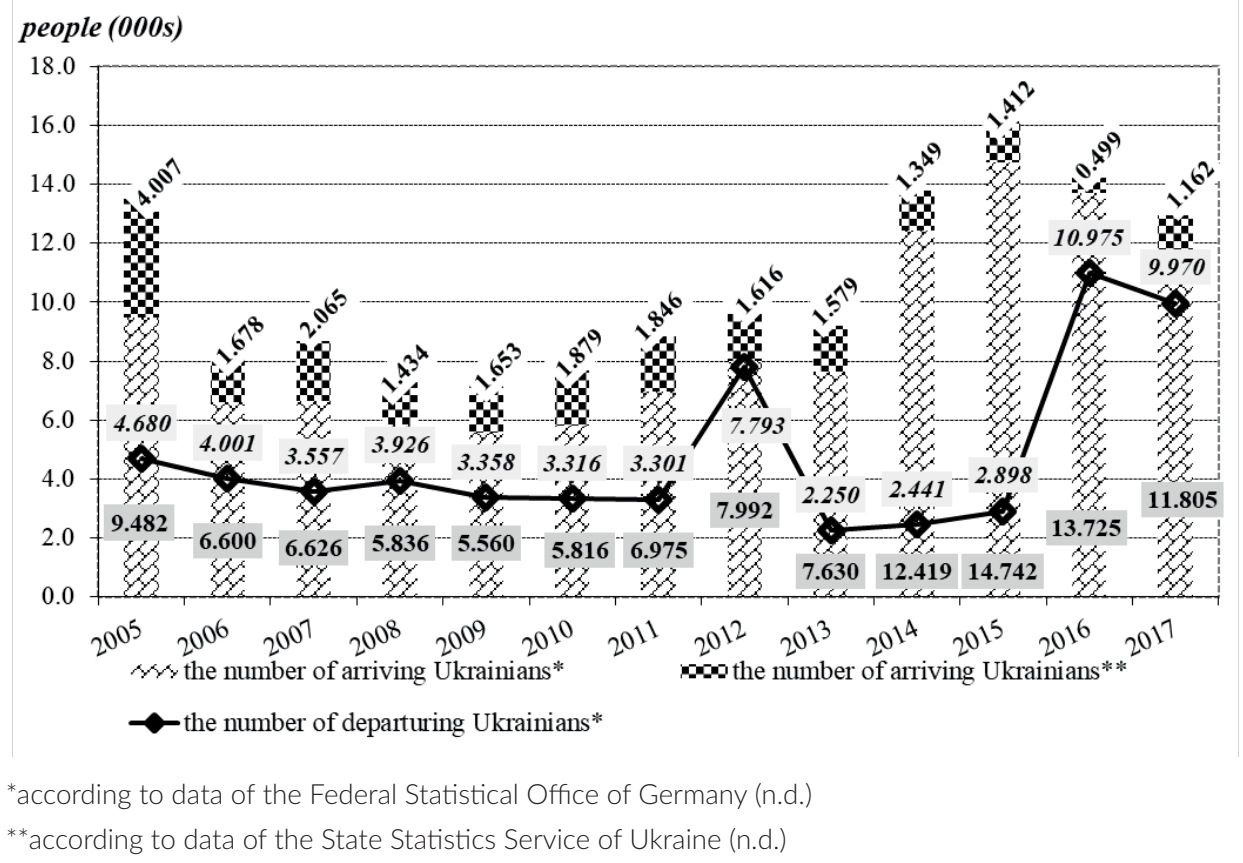

Figure 1. Number of arrivals and departures of Ukrainian nationals in Germany, 2005-2017 Source: authors' own compilation based on data from the State Migration Service of Ukraine, Migration Profile of Ukraine (n.d.) - years: 2005, 2007, 2010, 2012, 2014, 2017; Einbürgerungen (n.d.) - years: 2005, 2007, 2010, 2012, 2014, 2017.

In general, the number of Ukrainians and Germans with Ukrainian ethnic origin varied between 230,000 in 2006 and 319,000 in 2017 (Figure 2).

Analysis of the Ukrainian migration data (Figure 3) showed that in 2017, about $60 \%$ of the women and $50 \%$ of the men living in Germany were economically active and aged 25-54 years old. There are minor differences in the age structure of migrants: the median age of women is lower than that of men, and the proportion of children under 14 was $12 \%$ of boys and $5 \%$ of girls.

An important part of the study of the Ukraine-Germany migration vector is identifying the reasons for migration. The complexity of such analysis lies in the fact that the German migration legislation has been changed multiple times in recent years, and classification of the purposes for the foreign citizens' arrival in the Federal Republic of Germany has often been amended and clarified. Therefore, such indicators are not comparative in dynamics. The structural analysis of emigration purposes of Ukrainians to Germany as of the end of 2017 is shown in Figure 4. 


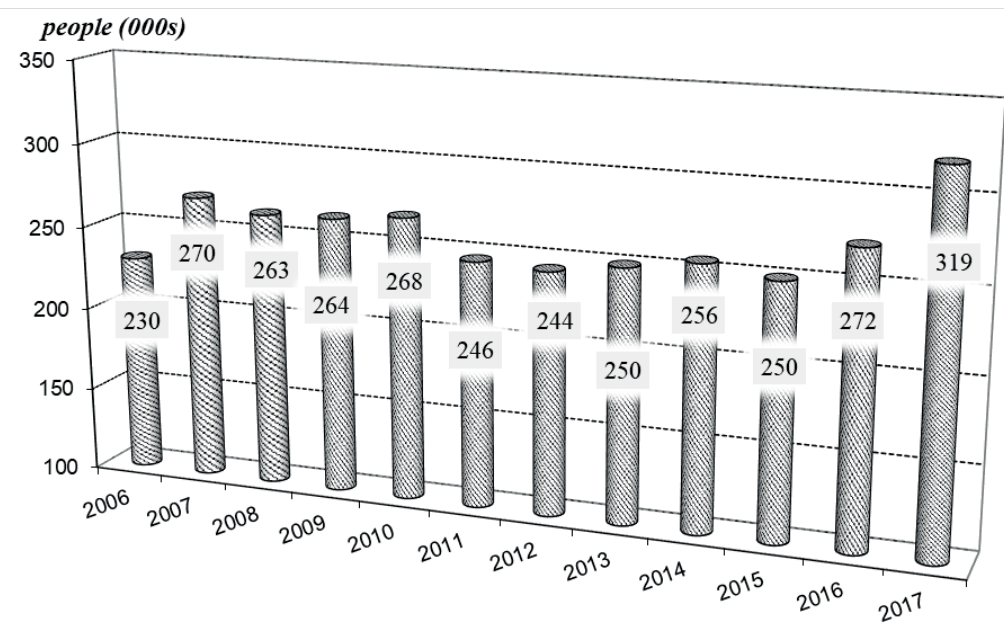

Figure 2. Number of ethnic Ukrainians in Germany, 2006-2017

Source: authors' own compilation based on data from Ausländische Bevölkerung (n.d.) - years: 2006, 2008, 2009, 2011, 2014, 2016, 2017.

The main purpose for the emigration of about $50 \%$ of Ukrainians is family reasons, and for $20 \%$ - education or work. According to the German Academic Exchange Service, in general, Ukrainian students in Germany ranked sixth among all foreign students. About 9,000 young people from Ukraine study and conduct research in German universities. Some of them are members of the Union of Ukrainian Students in Germany. Before the intensification of educational migration from Ukraine to Poland, Germany was the leader among other countries (except for Russia) in the number of Ukrainian students.

It is necessary to consider the territorial aspect of migration processes when evaluating the Ukraine-Germany migration vector. Intensive territorial mobility causes changes not only in the gender and age distribution of the population but also in the settlement structure of the country, creating pull-push centres of human resources. Such centres form the framework of migration systems, including the Ukrainian-German one.

As of the beginning of 2018, the largest number of Ukrainians lived in the southern and eastern states of Germany, namely in Berlin (309 per 100,000 people), Hamburg (215 per 100,000 people), Bremen (206 per 100,000 people), Mecklenburg-Vorpommern (246 per 100,000 people) and Bavaria (211 per 100,000 people). The results of the territorial distribution of migrants confirm the existence of a strong direct correlation between the employment rate of the population and the number of Ukrainians, as suggested by the federal states of Germany. 


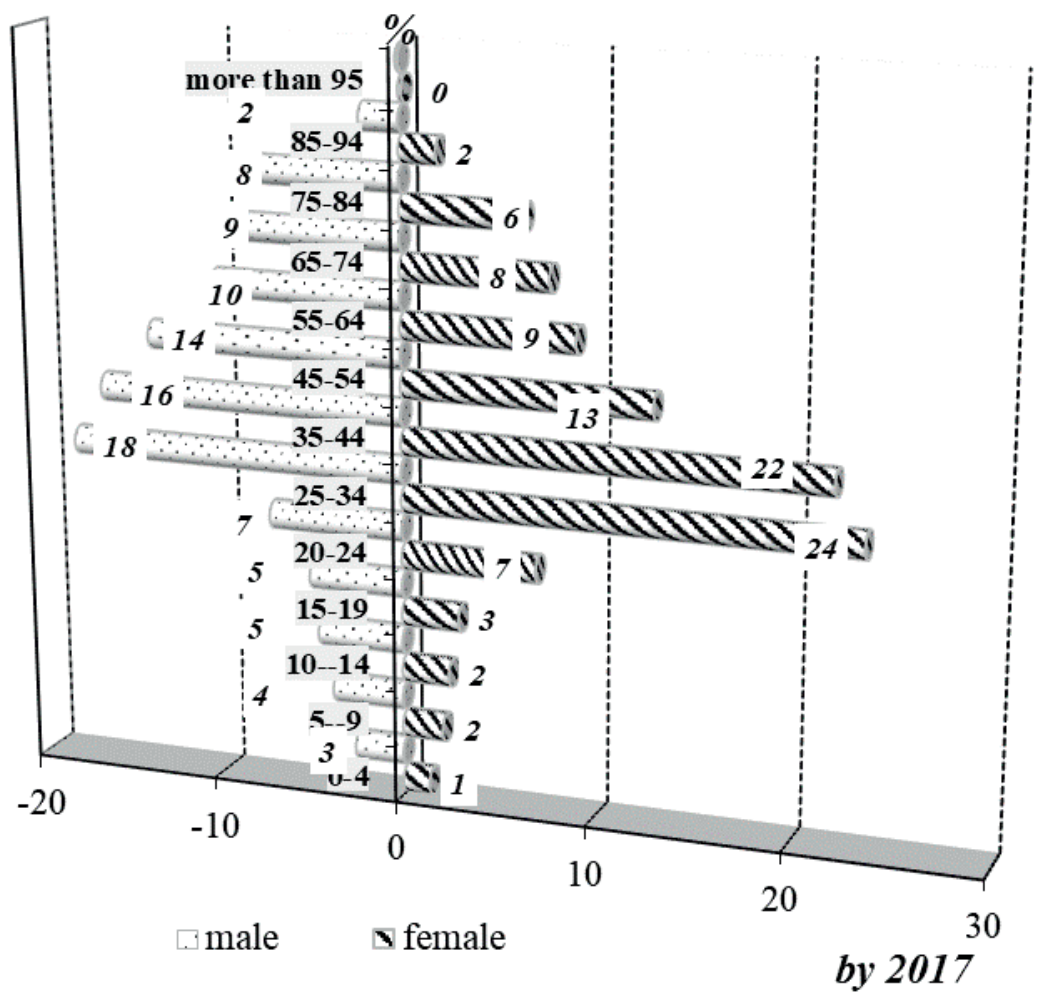

Figure 3. Gender and age structure of Ukrainians living in Germany, 2017

Source: authors' own compilation based on data from Ausländische Bevölkerung (n.d.) - year: 2017.

The Ukraine-Germany migration flow has a steady and integral character as opposed to the Germany-Ukraine migration flow, which is non-systemic and insignificant in size. According to the All-Ukrainian Census of 2001, about 33,000 Germans lived in Ukraine as of that time. The average density was 69 people per 100,000 population (All-Ukrainian Population Census 2001). In territorial terms, two areas of a denser residence of Germans in Ukraine can be distinguished: the west and south-east. Thus, the Zakarpattia region had the highest concentration of Germans - 284 per 100,000 population, and in the south-eastern part of Ukraine (Dnipropetrovsk, Kherson, Zaporizhzhya, Odesa regions and the Autonomous Republic of Crimea) - about 110 per 100,000 population. According to the State Statistics Service of Ukraine, in 20102017 more than 3,000 people moved from Germany to Ukraine for permanent residence, of which about 40\% were Ukrainians and 1,600 were citizens of the European countries, including Germany (State Statistics Service of Ukraine 2018). 


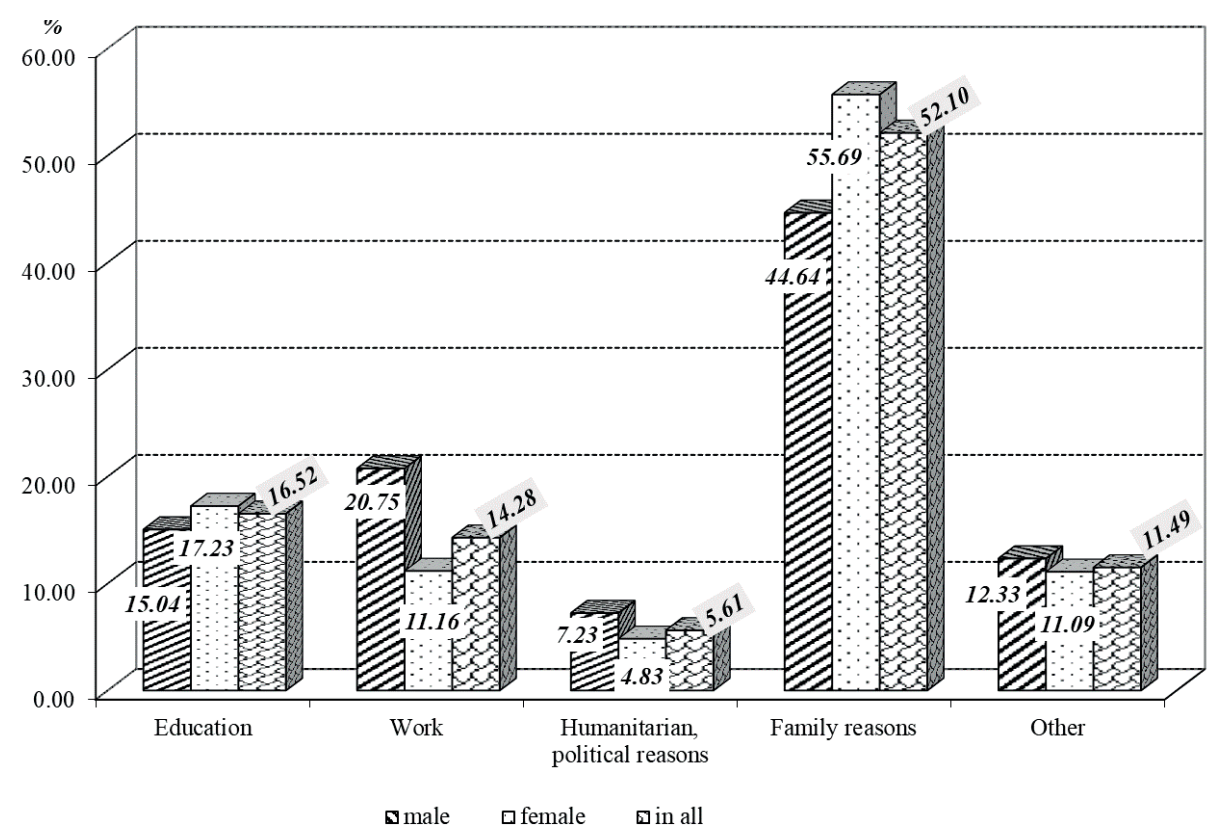

Figure 4. Reasons for Ukrainians' emigration to Germany, as of 1.01.2018

Source: authors' own compilation based on data from Ausländische Bevölkerung (n.d.) - year: 2018.

\section{Modelling the Ukraine-Germany migration vector}

A significant deformation of the age structure of an indigenous population is the result of a nation's hyper-ageing. It is of note that "indigenous population" as a term refers to citizenship or living in a country for a certain period, or the fact that previous generations of relatives live in the country. In this regard, fundamental changes in the age structure of the population can lead to demographic collapse, which makes a country's economic growth impossible due to workforce shortages in the national labour market. Such trends greatly contribute to increasing the state budget expenditures on financing the pension fund and other social protection structures.

These arguments confirm the initial statement regarding the dependence of the German economy on human migration flows from other states. Their intensity must increase from year to year in order to minimize the consequences of the demographic crisis and avoid a significant imbalance in the labour market. As evidenced by the data in Table 2, positive annual net migration of about 300,000 people is sufficient to maintain a stable demographic situation in Germany by 2030. However, according to the forecast for the period 2030-2060, annual net migration should increase to 0.5 million people to offset natural population losses in the country.

Retrospective analysis of the local population size and structure showed that the population in Germany remained almost constant throughout the period analysed. 
The high proportion of immigrants caused this situation, and the trend is expected to continue for another 10-20 years. It should also be mentioned that during this period, the difference between the actual data and the reference data will be balanced by the large scale of migration. In this case, in 2030, about 16 million migrants may live in the Federal Republic of Germany, which amounts to $20 \%$ of the indigenous population. In 2050, one in three residents in Germany and almost every second resident in 2060 will have migrant status or an immigrant background.

Table 2. German population forecast including migration by 2060

\begin{tabular}{|c|c|c|c|c|c|c|c|c|c|}
\hline \multicolumn{9}{|c|}{ Actual values, millions of people } & Growth rate \\
\hline 2000 & \multicolumn{3}{|c|}{2005} & \multicolumn{2}{|c|}{2010} & \multicolumn{3}{|c|}{2015} & $2015 / 2000$ \\
\hline 82.26 & \multicolumn{3}{|c|}{82.44} & \multicolumn{2}{|c|}{81.75} & \multicolumn{3}{|c|}{82.18} & 0.998 \\
\hline \multicolumn{9}{|c|}{ Projected values, millions of people } & Growth rate \\
\hline 2020 & 2025 & 2030 & 2035 & 2040 & 2045 & 2050 & 2055 & 2060 & $2060 / 2015$ \\
\hline \multicolumn{10}{|c|}{$m=0$} \\
\hline 80.65 & 77.45 & 75.50 & 73.34 & 71.00 & 68.47 & 65.74 & 62.94 & 60.23 & 0.733 \\
\hline \multicolumn{10}{|c|}{$0<m<100$} \\
\hline 81.44 & 80.51 & 79.23 & 77.70 & 75.96 & 74.03 & 71.90 & 69.70 & 67.57 & 0.822 \\
\hline \multicolumn{10}{|c|}{$100<m<200$} \\
\hline 81.82 & 81.32 & 80.61 & 79.73 & 78.66 & 77.42 & 76.08 & 74.76 & 74.78 & 0.910 \\
\hline \multicolumn{10}{|c|}{$200<m<300$} \\
\hline 83.01 & 82.85 & 82.26 & 81.53 & 80.27 & 79.45 & 78.56 & 77.76 & 77.74 & 0.946 \\
\hline
\end{tabular}

$m$ - scope of migration in millions of people

Source: authors' calculations.

Ukraine's demographic prospects for natural reproduction depend on specific modern trends, e.g., the large-scale internal (with the prospect of becoming external) and external migration in Ukraine as a result of the military conflict in Donbas, the consequences of increasing poverty, which is provoking emigration and thus a reduction in population, as well as Ukraine being the European leader in AIDS, tuberculosis, measles and other infectious diseases. Such a scenario is confirmed by the results of research conducted by scientists of the Ptoukha Institute for Demography and Social Studies of the National Academy of Sciences of Ukraine (Poznyak and Shevchuk 2014). According to estimates, the most likely scenario is a decline in Ukraine's population, from 42.4 million people in 2017 to 37.1 million at the beginning of 2060 . The lower limit of the population size is projected at around 28.3 million people. If, during the period covered by the forecast, the natural and migratory movement trends persist, the number of Ukrainians will reach 32.4 million at the beginning of 2060, which is 10 million less than in 2017.

Considering the age structure of the population in the medium and long-term, a decrease in the share of people of active working age is expected in Ukraine. At the same time, according to some variants of the forecast, the indicator may fluctuate between 
$47.7 \%$ and $55.3 \%$ at the beginning of 2060. If the trend of the ageing and worsening of the population age structure in Ukraine persists, it will further lead to a shortage of labour resources in the domestic labour market.

According to calculations, the long-term unilateral impact of socio-economic factors stimulated the development of, specifically, the Ukraine-Germany migration vector, and not vice versa. It should be noted that model (2) shows how any changes in the factor values can lead to a transformation in Ukrainian emigrants' behaviour. The results of the mathematical economic model estimation are presented in Table 3. In particular, about $88 \%$ of the change in the growth rate of the coefficient of the intensity of Ukrainian emigration to Germany for the period 2006-2017 is caused by the factors included in the model (the coefficient of determination is 0.876 ). There is a strong correlation between the rate of Ukrainians' emigrating to Germany and socio-economic factors, as evidenced by the multiple correlation coefficient, which is equal to 0.91 .

$$
\begin{gathered}
C O E F=1.091+0.349 I N F^{U A}+0.825 E F^{E C}-0.284 S A L^{G E R M}- \\
-0.575 S A L^{U A}-0.698 U N E M P^{G E R M} \\
\begin{array}{c}
\text { adj. } R^{2}=0.876 \\
D W=1.59
\end{array}
\end{gathered}
$$

To determine the level of importance and influence of each factor on the dependent variable variation, the coefficients of elasticity were calculated, which showed that with a $1 \%$ increase in inflation rates in Ukraine $\left(I N F^{U A}\right)$ and with constant values of other factors, a $1.08 \%$ increase in the intensity of Ukrainians' migration to Germany is expected. A $1 \%$ increase in the average wage in Ukraine $\left(S A L^{U A}\right)$ and unemployment in Germany (UNEMP $P^{G E R M}$ ) leads to a $2.01 \%$ and $2.2 \%$ migration decline, respectively. In general, the model estimation results revealed that with a $1 \%$ increase in the variable values presented in the model, the dependent variable (COEF) would decrease by $3.13 \%$.

Table 3. Model estimation results

\begin{tabular}{|l|c|l|c|}
\hline \multicolumn{1}{|c|}{ Criteria } & Values & \multicolumn{1}{c|}{ Criteria } & Values \\
\hline $\begin{array}{l}\text { Coefficient of determination } \\
\text { (R-squared) }\end{array}$ & 0.875670 & $\begin{array}{l}\text { Standard error } \\
\text { of dependent variable }\end{array}$ & 1.000000 \\
\hline Adjusted R-squared & 0.772062 & p-value & 0.010893 \\
\hline Standard error of regression & 0.477428 & Akaike info criterion & 1.666047 \\
\hline Sum squared resid & 1.367626 & Schwartz criterion & 1.908500 \\
\hline Log likelihood & -3.996282 & Hannan-Quinn criterion & 1.576282 \\
\hline F-statistic & 8.451759 & Durbin-Watson statistic & 1.592582 \\
\hline
\end{tabular}

Source: authors' calculations.

The values of partial correlation coefficients, as well as coefficients of elasticity, confirm the hypothesis that the system of socio-economic factors is driving the process of developing the Ukraine-Germany migration vector. 
In case of economic growth in Ukraine and constant economic progress in Germany, provided for by the reference scenario, the number of Ukrainians, who move annually to Germany, will remain at the level of 10-12,000 people per year until 2025 with a sharp decline in 2030 (to 1,500 people). Thus, the ethnic Ukrainian community will grow to 380,000 people by 2025 (Table 4).

Table 4. Forecast of the number of ethnic Ukrainians in Germany by 2030: a scenario approach

\begin{tabular}{|l|c|c|c|r|r|c|}
\hline \multicolumn{1}{|c|}{ Forecast data, people (000s) } & $\mathbf{2 0 2 0}$ & $\mathbf{2 0 2 3}$ & $\mathbf{2 0 2 6}$ & $\mathbf{2 0 2 9}$ & $\mathbf{2 0 3 0}$ & $\mathbf{2 0 3 0 / 2 0 1 7}$ \\
\hline Reference & 343 & 366 & 381 & 381 & 378 & 1.19 \\
\hline Optimistic & 332 & 332 & 324 & 313 & 309 & 0.97 \\
\hline Tendentious & 347 & 379 & 414 & 438 & 445 & 1.39 \\
\hline Pessimistic & 363 & 448 & 585 & 750 & 811 & 2.54 \\
\hline Crisis & 378 & 515 & 789 & 1210 & 1392 & 4.36 \\
\hline
\end{tabular}

The number of ethnic Ukrainians in Germany in 2017 was 319,000 people.

Source: authors' calculations.

According to this scenario, the change in the trend is associated with the equalisation of values of the main indicators that act as a booster to migration activity, namely wages, unemployment and inflation. In 2030, with an average wage of 3000 EUR per year (authors' estimation according to the reference scenario), both in Ukraine and Germany, the personal economic benefit from migration will be too low - approximately 33 million EUR per year (Table 5). Under such conditions, the number of potential emigrants from Ukraine could be significantly reduced, and systematic labour migration could evolve into educational or tourist-family migration. As a result, the new migratory movements of Ukrainians will appear to be more stochastic than deliberate and regular.

In addition to the economic factors, the decrease in mobility of the citizens of Ukraine in the period 2025-2030 in the reference forecasting scenario can be explained by particular features of the main characteristics of Ukraine's population. The acute demographic crisis and, consequently, the labour force crisis are caused by the migration of human resources in the young and middle age, combined with low birth rates during the beginning of the $21^{\text {st }}$ century. Therefore, preserving the number and optimizing the age structure of the population of Ukraine, as important characteristics of the national economic security, are pressing issues today. Ukraine's potential economic success will be impossible to realise without a skilled labour force in the future. Upon achieving sustainable economic growth, the demand for personnel will increase exponentially. To enhance people's well-being, labour market mobilisation using not only internal resources but also external ones is required. It should also be noted that the economic revival of Ukraine is the basis for its transforming from a donor labour country to a recipient country. At the same time, one should not expect an increase in the intensity of migration flows from Germany to Ukraine. 
Table 5. Forecast of personal economic benefits of employed ethnic Ukrainians in Germany: a scenario approach, million EUR per year

\begin{tabular}{|c|c|c|c|c|c|c|c|c|c|}
\hline \multicolumn{4}{|c|}{ Actual data } & \multicolumn{6}{|c|}{ Forecast data/development scenarios } \\
\hline 2006 & 2010 & 2014 & 2017 & 2020 & 2023 & 2026 & 2029 & 2030 & $2030 / 2017$ \\
\hline 52.9 & 97.2 & 94.2 & 181.4 & \multicolumn{6}{|c|}{ Reference } \\
\hline & & & & 350 & 284 & 182 & 61 & 33 & 0.18 \\
\hline & & & & \multicolumn{6}{|c|}{ Optimistic } \\
\hline & & & & 189 & 64 & 17 & 3 & 1 & 0.005 \\
\hline & & & & \multicolumn{6}{|c|}{ Tendentious } \\
\hline & & & & 391 & 353 & 297 & 203 & 182 & 1.003 \\
\hline & & & & \multicolumn{6}{|c|}{ Pessimistic } \\
\hline & & & & 605 & 830 & 1027 & 1026 & 1029 & 5.67 \\
\hline & & & & \multicolumn{6}{|c|}{ Crisis } \\
\hline & & & & 831 & 1265 & 1843 & 2249 & 2420 & 13.34 \\
\hline
\end{tabular}

Source: authors' calculations.

The results of the optimistic forecast scenario of Ukrainians' migration to Germany demonstrate the improvement in the economic situation in Ukraine, in contrast to Germany, where economic deterioration is predicted. Unemployment growth in Germany against a possible economic miracle in Ukraine could create conditions to effectively regulate the population's migration activity in terms of tourism, rather than labour activity, even before 2025 .

According to the results of the analysis carried out by the method of system dynamics, the probability of rapid rates of economic growth in Ukraine and minimising economic losses due to labour migration is very low. The difficult military and political situation, the two economic crises of the $21^{\text {st }}$ century, accompanied by a significant devaluation of the national currency, hyper-growth of prices, high unemployment and corruption scandals nullified the economic breakthroughs in Ukraine. Consequently, actual and potential labour migration is growing, as well as a lack of belief of many young Ukrainians in the possibility of improving their wealth and personal development in the country. The reference and optimistic forecasts allow us to determine parity scenarios according to which the states can develop to achieve the economic and demographic balance (Mulska and Baranyak 2019).

The presented tendentious forecast scenario shows a moderate growth of economic and social standards in Ukraine, which is the most acceptable scenario for Ukraine. In absolute terms, the intensity of the Ukraine-Germany migration flows will increase to 400,000 people in 2025 and 450,000 people in 2030. Between 2019 and 2027, the average annual number of new immigrants from Ukraine will fluctuate between 13,000 and 15,000 people, gradually decreasing to 10,000 people in 2030 .

According to the medium and long-term forecasts, the number of employed ethnic Ukrainians will remain at the level of approximately 200,000 people (Table 6). The income gap of citizens will increase by $1.003 \%$, from 181.4 million EUR per year 
in 2017 to 182 million EUR per year in 2030 (based on the authors' tendentious forecast data).

Table 6. Forecast of the number of employed ethnic Ukrainians in Germany by 2030: a scenario approach

\begin{tabular}{|c|c|c|c|c|c|c|c|c|c|}
\hline \multicolumn{4}{|c|}{ Actual data, people (000s) } & \multicolumn{6}{|c|}{ Forecast data, thousand people/development scenarios } \\
\hline 2006 & 2010 & 2014 & 2017 & 2020 & 2023 & 2026 & 2029 & 2030 & $2030 / 2017$ \\
\hline 63 & 97 & 109 & 144 & \multicolumn{6}{|c|}{ Reference } \\
\hline & & & & 165.3 & 181.1 & 185.3 & 174.8 & 169.9 & 1.18 \\
\hline & & & & \multicolumn{6}{|c|}{ Optimistic } \\
\hline & & & & 153.3 & 150.0 & 137.7 & 123.7 & 119.1 & 0.83 \\
\hline & & & & \multicolumn{6}{|c|}{ Tendentious } \\
\hline & & & & 166.9 & 187.9 & 201.4 & 201.3 & 199.7 & 1.39 \\
\hline & & & & \multicolumn{6}{|c|}{ Pessimistic } \\
\hline & & & & 174.9 & 221.9 & 284.0 & 344.5 & 364.2 & 2.53 \\
\hline & & & & \multicolumn{6}{|c|}{ Crisis } \\
\hline & & & & 182.0 & 255.0 & 383.5 & 556.0 & 625.3 & 4.34 \\
\hline
\end{tabular}

Source: authors' calculations.

Under a pessimistic scenario of the development of Ukraine's economy, which reflects an increase in the average wage by $10 \%$ per year and a simultaneous rise in prices by $20 \%$, the deformation of the Ukraine-Germany migration vector will only intensify. The growing poverty among Ukrainians might cause a significant scaling-up of the flows of migrants through the Ukraine-Germany migration channel. With such constant values of factors, the number of arrivals from Ukraine will steadily grow, and the number of ethnic Ukrainians officially living in Germany will increase threefold (to more than 800,000 people) by 2030 .

A large gap in the incomes of citizens of Ukraine and other EU countries is a major factor in the migrants' choice of a potential migration system, country of employment or permanent residence. This is reflected in the nine times growth of personal economic benefits (from 181.4 million EUR in 2017 to 881.8 million EUR in 2030) and in an increase in the number of employed ethnic Ukrainians in Germany (from 144,000 to 364,000 people between 2017 and 2030).

\section{Conclusions}

Future capacities in forecasting migration processes require not only new and more innovative methods and predictive models, but also a new philosophy in understanding actual forecasts and their significance for government regulation of migration activity. The methods and tools should be based on reasonable forecasts in line with the development of major migration systems. 
Given the demographic situation in Ukraine and the results of forecasting the Ukraine-Germany migration vector, the strategic guidelines of state policy should be as follows:

1. Ensure the proper level of controllability of the Ukraine-Germany migration trends in the short, medium and strategic perspectives.

2. Form a system of factors and motivations for return migration to Ukraine and retain its human resources.

3. Activate mutually beneficial migration exchanges in terms of employment, tourism, education, science, research and innovation activities, investment and business projects.

4. Develop common positive practices and experience in effective state regulation of migration processes, the convergence of the institutional system of migration regulation with advanced models in the $\mathrm{EU}$, and counteract modern migration challenges and threats to Ukraine.

The primary tools to implement the state migration policy in the framework of the Ukrainian-German migration system should be:

1. Monitoring the quantitative and structural characteristics of migration by the leading (according to scales and trends) countries (regions) to create a relevant qualitative and comprehensive information and analytical basis to develop effective management decisions. This requires assigning respective tasks and expanding the authorities of the regional offices of the State Migration Service of Ukraine (in cooperation with the territorial bodies of the State Border Service of Ukraine).

2. In terms of the current Strategy of the State Migration Policy of Ukraine for the period up to 2025 (No. 482-p dated February 7, 2017), developing (by the Ministry of Social Policy of Ukraine), adopting and implementing the Program of measures aimed at regulating the Ukrainian-German migration processes, dividing tasks into current, medium-term and strategic ones (in accordance with the demographic and migration forecasts defined in the research).

3. Introducing new institutional tools to stimulate return migration (especially educational and labour migration) to Ukraine. Realising the objectives and activities of this tool provides for the harmonisation of provisions and the conclusion of interstate agreements in the areas of education, training, employment and migration, to "embed" effective factors that motivate people to return. The latter is related to:

- guarantees of preserving jobs and places in educational institutions; projects of interregional cooperation in the framework of educational and labour exchange and mobility;

- tax and fiscal holidays as well as financial and economic incentives for investing;

- organisational and other support in creating new types of business in Ukraine;

- legalising intermediaries' activities in the market of migration services by creating high-quality, transparent infrastructure of the Ukrainian-German migration system. 
4. Strengthening internal factors to deter external labour migration from Ukraine and encouraging gradual migration of German specialists to Ukraine. This requires intensifying relevant efforts, and coordinating the activities of Ukrainian and German departments and divisions of the Ministry of Social Policy, the State Labour Service, employers' organisations, business associations, domestic and international organisations on labour, employment and migration, as well as leading corporations.

As part of this tool, the further development and setting up new German-invested enterprises in Ukraine could become an effective institutional platform that helps create new jobs and decent working conditions, attract advanced western technologies, increase exports and imports, and drive up real wages as a source of income for the population and as an important incentive to work. Today, more than 4000 enterprises with German capital are officially registered in Ukraine (e.g., Kromberg \& Schubert, Bader-Ukraine, Forschner Ukraine, Leoni-Ukraine, Kostal Ukraine, HeidelbergCement, KNAUF Gypsum Donbass, Klingspor-Ukraine, Henkel Bautechnik Ukraine in the automotive component industry and in construction; Pfeifer \& Langen Ukraine, Toepfer International Company (Alfred C. Toepfer International $\mathrm{GmbH}$ ) in the agricultural sector; and Metro Cash \& Carry in trade).

5. Integrating re-emigrants and immigrants from Germany into Ukrainian society. The process of integrating and adapting migrants implies providing assistance in finding an acceptable job, introducing a state system of affordable lending, offering tax breaks for migrants who wish to start their own business in Ukraine, and also negotiating with the German government to develop and implement programs for the voluntary return of migrants and to reintegrate them in their country of origin jointly with Ukraine on a shared funding basis.

Creating a special central authority to develop and implement state migration policy (according to the practice of the states with highly effective migration policies - the Ministry of external migration relations) is becoming increasingly urgent for Ukraine. Its main functions will include expanding legal channels of the Ukrainian citizens' employment in the recipient countries, protecting the rights of Ukrainian labour migrants, and concluding interstate agreements on social security and pension provision for migrant workers.

Implementing these tools will make it possible to transform the environment that affects the Ukraine-Germany migration vector into a more predictable and manageable one, able to advance the social, humanitarian and economic interests of Ukraine, Germany and their citizens (actual and potential migrants). It will also create new effective incentives to revive immigration, including attracting qualified German specialists, and it will serve as additional pull-factors of labour migration in Ukraine to reduce imbalances in the national labour market and increase social guarantees and living standards. 


\section{References}

All-Ukrainian Population Census (2001), Statistics Database, http://www.ukrcensus .gov.ua/eng/ (accessed: 15.05.2019).

Ausländische Bevölkerung (n.d.), https://www.destatis.de/DE/Publikationen/Thema tisch/Bevoelkerung/MigrationIntegration/AuslaendBevoelkerung.html (accessed: 2.05.2019).

Bijak, J. (2006), Forecasting international migration: Selected theories, models, and methods, CEFMR Working Paper 4, Central European Forum for Migration Research, Warsaw, https://pdfs.semanticscholar.org/c67f/39cc621207bf34c63f371108 a6021102744f.pdf (accessed: 2.05.2019).

Bil, M. (2017), Retrospective survey of spatial mobility of the population, "Demography and Social Economics", 1, pp. 66-78, https://doi.org/10.15407/dse2017.01.066

Einbürgerungen (n.d.), https://www.destatis.de/DE/Publikationen/Thematisch/Bevo elkerung/MigrationIntegration/Einbuergerungen.html (accessed: 31.05.2019).

Federal Statistical Office of Germany. Statistics Database (n.d.), https://www-genesis .destatis.de/genesis/online/data (accessed: 2.06.2019).

Hyndman, R.J., Booth, H. (2008), Stochastic population forecasts using functional data models for mortality, fertility and migration, "International Journal of Forecasting", 24 (3), pp. 323-342, https://doi.org/10.1016/j.ijforecast.2008.02.009

Keilman, N., Pham, D.Q. (2004), Empirical errors and predicted errors in fertility, mortality and migration forecasts in the European Economic Area, Discussion Paper, No. 386, Social and Demographic Research, Statistics Norway, https://www.resear chgate.net/publication/24132711_Empirical_errors_and_predicted_errors_in_fer tility_mortality_and_migration_forecasts_in_the_European_Economic_Area (accessed: 11.07.2019).

"Kurier" (2018), Bevölkerung: Westeuropa wächst, Osteuropa schrumpft, https://kuri er.at/chronik/weltchronik/bevoelkerung-westeuropa-waechst-osteuropa-schrump $\mathrm{ft} / 400054985$ (accessed: 4.06.2019).

Libanova, E. (2010), Population of Ukraine. Labour emigration in Ukraine, Ptoukha Institute for Demography and Social Studies of the National Academy of Sciences of Ukraine, Kyiv.

Libanova, E.M., Pozniak, O.V., Makarova, O.B., Sarioglo, V.G., Tkachenko, L.G. (2009), External labour migration of population, Ukrainian Centre for Social Reforms, Kyiv.

Mahmoud, O., Trebesch, T., Trebesch Ch. (2010), The economics of human trafficking and labour migration: Micro-evidence from Eastern Europe, "Journal of Comparative Economics”, 38, pp. 173-188, https://doi.org/10.1016/j.jce.2010.02.001

Malynovska, O. (2013), The policy of neighbouring countries with regard to compatriots as an instrument for replenishing human resources: challenges and lessons for Ukraine, "Strategic Priorities", 3 (28), pp. 138-146.

Malynovska, O. (2015a), Labour migration of Ukrainian population: what to expect at the nearest future?, "Migration (Electronic Analytical Newspaper)". April 29, http://migraciya.com.ua/upload/d75da205ca27e012961fe39b5b3da33c.pdf (accessed: 15.05 .2019$)$. 
Malynovska, O. (2015b), Possible development of labour migration abroad in the context of current situation in Ukraine, "Journal of Pension Fund of Ukraine", 3 (153), pp. 10-15.

Mansoor, A., Quillin, B. (2006), Migration and Remittances: Eastern Europe and the Former Soviet Union, The World Bank, Washington, https://doi.org/10.1596/978 -0-8213-6233-4

Mulska, O., Baranyak, I. (2019), Formation of the forecasting model for Ukrainian-German migration system, "Economy and Forecasting", 2, pp. 119-136, https://doi.org /10.15407/econforecast2019.02.119

Ovchynnikova, O. (2017), Models of Regional Migration of the Population, "Intelekt XXI ", 4, pp. 27-32.

Poznyak, O., Shevchuk, P. (2014), Demographic perspectives of Ukraine until 2060, "Demography and Social Economy”, 1 (21), pp. 72-84, https://doi.org/10.15407/dse20 14.01.072

Sadova, U., Hrynkevych, O., Semiv, L., Teslyuk, R., Bil, M., Bidak, V., Ryndzak, O., Levytska, O., Mulska, O. (2019), Ukrainian migration in the context of the global and national challenges of the $21^{\text {st }}$ century, International Labour Organization in Ukraine, Dolishniy Institute of Regional Research of the National Academy of Sciences of Ukraine, Lviv Polytechnic National University, Lviv.

Sarioglo, V.G. (2016), Great data as a source of information and tools for official statistics: potential, problems, perspectives, "Statistics of Ukraine", 4, pp. 12-19.

State Migration Service of Ukraine (2017), Migration profile of Ukraine. State Migration Service of Ukraine, Kyiv, https://dmsu.gov.ua/assets/files/mig_profil/migprofil _2017.pdf (accessed: 14.06.2019).

State Statistics Service of Ukraine (2018), Population of Ukraine in 2017. Demographic Yearbook, Kyiv, http://database.ukrcensus.gov.ua/PXWEB2007/ukr/publ_new1/20 18/zb_dy_2017.pdf (accessed: 2.07.2019).

State Statistics Service of Ukraine. Statistics Database (n.d.), http://www.ukrstat.gov .ua (accessed: 10.06.2019).

Wickramasekara, P. (2008), Globalisation, international labour migration and rights of migrant workers, "Third World Quarterly: Special Issue on Globalisation and Migration: New Issues, New Politics”, 29 (7), pp. 1247-1264, https://doi.org/10.10 $80 / 01436590802386278$ 


\section{Aspiracje migracyjne Ukraińców do Niemiec: analiza i scenariusze rozwoju}

Na podstawie modelu regresji wielokrotnej i podejścia scenariuszowego do prognoz oszacowano ukraińskie aspiracje migracyjne do Niemiec (skala migracji, aktywność gospodarcza migrantów i ich korzyści ekonomiczne). Argumentuje się, że poważne zmiany w strukturze wiekowej i płci ludności lokalnej mogą powodować kryzys demograficzny i utratę równowagi na rynku pracy. Przedstawione prognozy wskazują na rosnącą rolę zagranicznych zasobów ludzkich w niemieckiej gospodarce. Modelując skalę emigracji z Ukrainy zastosowano podejście zintegrowane, uwzględniające nie tylko trendy czynników przyciągających, ale także szczególne aspekty niemieckiej polityki migracyjnej i odpływ 8-10 milionów ukraińskich pracowników. Biorąc pod uwagę brak wystarczających danych statystycznych dotyczących skali emigracji zarobkowej, potrzebnych do budowy wiarygodnych modeli ekonometrycznych, uzasadniono, że zastosowanie eksperckiej metody prognozowania pozostaje optymalną techniką oceny potencjalnych przepływów migracyjnych i systemów migracji.

Słowa kluczowe: aspiracje migracyjne, czynniki społeczno-ekonomiczne, prognoza, polityka migracyjna, Ukraina, Niemcy 